\title{
Development and Pilot Testing of a Five Item Traumatic Stress Screener for Use with Adolescents in Pediatric Primary Care
}

Short title: Adolescent Primary Care Traumatic Stress Screen

${ }^{*}$ Lauren C. Ng, PhD, University of California Los Angeles Department of Psychology; previously Boston University and Boston Medical Center Department of Psychiatry Rachel Oblath, PhD, Boston Medical Center Department of Psychiatry Rebecca Brigham, LICSW, Boston Medical Center Department of Pediatrics

Ming Him Tai, University of Minnesota, previously Boston University Department of Psychology and Boston Medical Center Department of Psychiatry

Mandy Coles, MD, Boston University and Boston Medical Center Department of Pediatrics

*Corresponding Author: Lauren C. Ng, PhD

Psychology Building 1285, Box 951563

Los Angeles, CA 90095-1563

Email: laurenng@ucla.edu

Cell: 202-997-3301 
medRxiv preprint doi: https://doi.org/10.1101/2022.02.11.22270757; this version posted February 15, 2022. The copyright holder for this preprint (which was not certified by peer review) is the author/funder, who has granted medRxiv a license to display the preprint in perpetuity.

It is made available under a CC-BY-NC-ND 4.0 International license .

Adolescent Primary Care Traumatic Stress Screen

Development and Pilot Testing of a Five Item Traumatic Stress Screener for Use with Adolescents in Pediatric Primary Care

\section{Abstract}

4 Objectives: To develop and assess the psychometric properties of the Adolescent Primary Care

5 Traumatic Stress Screen (APCTSS), a five-item yes/no screener for PTSD symptoms in

6 adolescents, and the first developed for pediatric primary care.

7 Study Design: The APCTSS was developed by combining and adapting the UCLA PTSD

8 Reaction Index for DSM-5 with the adult Primary Care PTSD Screen for DSM-5. Adolescent

9 medicine patients were universally approached during clinic visits. With a response rate of

$1083.6 \%, 178$ patients aged $13-22(M=18.4, S D=2.3), 64.4 \%$ female; $62.1 \%$ Black or African-

11 American and 20.7\% Hispanic/Latinx, were enrolled. Patients completed APCTSS, Patient

12 Health Questionnaire for Adolescents (PHQ-A), and Child PTSD Symptom Scale for DSM-5

13 Interview (CPSS-5-I), and 61 completed the Traumatic Events Screening Inventory for Children

14 (TESI-C).

15 Results: $56.7 \%$ reported a criterion A trauma, 30.1\% met criteria for PTSD, $7.4 \%$ met criteria

16 for subsyndromal PTSD, and $19.0 \%$ for post-event impairing symptoms. Scores $\geq 2$ on the

17 APCTSS optimized sensitivity (.79; 95\% CI=.66 to .89) and specificity (.68; 95\% CI=.55 to .76)

18 for PTSD, with an area under the curve (AUC) of .79. Sensitivity (.86; 95\% CI=.65 to .90),

19 specificity (.77; 95\% CI=.60 to .90), and AUC (.86) were even stronger when the TESI-C was

20 used to assess criterion A for PTSD diagnosis. Over half (56.0\%) of patients who screened

21 positive on the APCTSS were missed by the PHQ-A.

22 Conclusions: The APCTSS shows promise as an internally consistent, valid, and effective tool

23 for identifying adolescents at high risk of PTSD and traumatic stress. 
medRxiv preprint doi: https://doi.org/10.1101/2022.02.11.22270757; this version posted February 15, 2022. The copyright holder for this preprint (which was not certified by peer review) is the author/funder, who has granted medRxiv a license to display the preprint in perpetuity. It is made available under a CC-BY-NC-ND 4.0 International license .

Adolescent Primary Care Traumatic Stress Screen

\section{Introduction}

Almost $80 \%$ of adolescents in the US have experienced a traumatic event (Turner et al., 2010), and approximately 7\% have post-traumatic stress disorder (PTSD; Merikangas et al.,

27 2010). PTSD is associated with school failure, high-risk sexual behaviors, suicide attempts,

28 substance abuse, relationship problems, involvement in the justice system, and poor physical

29 health outcomes (Greene et al., 2016). PTSD prevalence amongst adult primary care samples

30 ranges from $2 \%$ to $39 \%$ with a large proportion of heterogeneity explained by differential trauma

31 exposure (Greene et al., 2016). Unfortunately, PTSD and traumatic stress symptoms are

32 routinely unidentified in pediatric primary care (Gerson \& Rappaport, 2013), and most

33 pediatricians report that they lack adequate knowledge, skills, and comfort to discuss PTSD, and

34 only 10\% assess and treat PTSD (Banh et al., 2008).

35 Some of the difficulty with identifying patients with traumatic stress symptoms in primary

36 care may stem from the fact that typically individuals with PTSD symptoms do not

37 spontaneously report their mental health symptoms or trauma histories (Read et al., 2006;

38 Wurr \& Partridge, 1996). If health providers do not explicitly assess these symptoms, they are

39 usually missed. Indeed, PTSD detection rates in routine adult primary care have found detection

40 rates from $0 \%$ to a high of $52 \%$ (Greene et al., 2016). Therefore, screening for PTSD may be

41 necessary to detect patients who are coping with trauma-related symptoms. Luckily, research

42 with adult samples has found that most patients are comfortable reporting trauma-exposure and

43 PTSD symptoms on primary care screeners (Goldstein et al., 2017). Recently, adverse childhood

44 experiences (ACES) are being more routinely assessed in pediatric primary care (California

45 Department of Health Care Services, 2021). However, fewer than 20\% of trauma exposed youth

46 will develop PTSD (Alisic et al., 2014), thereby reducing the utility of screening for ACES to

47 identify youth most in need of trauma-focused mental health care.

48 Additionally, there is a lack of validated and feasible assessments for assessing traumatic

49 stress symptoms in pediatric primary care. Primary care requires brief and simple tools (Löwe et 
medRxiv preprint doi: https://doi.org/10.1101/2022.02.11.22270757; this version posted February 15, 2022. The copyright holder for this preprint (which was not certified by peer review) is the author/funder, who has granted medRxiv a license to display the preprint in perpetuity. It is made available under a CC-BY-NC-ND 4.0 International license .

Adolescent Primary Care Traumatic Stress Screen

50 al., 2005). However, most PTSD screeners for youth and adults have been developed and

51 validated in specialty mental health with clinical populations and have 17 or more items and

52 multiple response options (Foa et al., 2018; Steinberg et al., 2013). A few brief measures with

53 yes/no response options have been developed, but they predict future PTSD (Kenardy et al.,

54 2006) or assess acute stress, not PTSD (Kassam-Adams \& Marsac, 2016). The Child Trauma

55 Screen (CTS) is the only other PTSD screener for children and adolescents that has been

56 validated for use in primary care for adolescents (Lang \& Connell, 2018; Lang et al., 2021a; Lang

57 et al., 2021b). However, the CTS was developed in a community mental health clinic and

58 consists of four dichotomous trauma exposure items and six reaction items measured on a 4-

59 point Likert scale (Lang \& Connell, 2017). The only PTSD symptom scales developed for, and

60 validated in, primary care have been for adults (Spoont et al., 2013).

61 Few studies have investigated the implementation and feasibility of PTSD screening in

62 primary care, but studies suggest that even the longest screening tools take only 10 minutes to

63 complete (Spoont et al., 2013). However, given the very limited time available in busy primary

64 care practices, providers and researchers tend to prioritize brevity (Brewin, 2005), and often one

65 or two item screeners, such as the PHQ-2 (Kroenke et al., 2003), have more uptake in routine

66 care. However, one or two item PTSD screeners such as the Single-item PTSD Screener (SIPS;

67 Gore et al., 2008) and the PCL-2 (Lang et al., 2012) have been found to have weak psychometric

68 properties due to limited variation in response options (Spoont et al., 2013). In contrast, the

69 five-item Primary Care PTSD Screen (PC-PTSD) has reasonable psychometric properties (Prins

70 et al., 2016), and is widely used and accepted (Spoont et al., 2015). The characteristics of the PC-

71 PTSD that are attractive for use in primary care include: (1) being self-report, (2) being only 4 or

725 items long, (3) focusing on meaningful empirically supported symptoms, (4) not utilizing

73 Likert-style responses, (5) not requiring an interview about trauma exposure, (6) focusing on

74 current PTSD, and (7) having psychometrics from primary care (Prins et al., 2003). 
medRxiv preprint doi: https://doi.org/10.1101/2022.02.11.22270757; this version posted February 15, 2022. The copyright holder for this preprint (which was not certified by peer review) is the author/funder, who has granted medRxiv a license to display the preprint in perpetuity. It is made available under a CC-BY-NC-ND 4.0 International license .

Adolescent Primary Care Traumatic Stress Screen

Given that a wide range of stress-related symptoms in childhood confer a transdiagnostic

76 diathesis for mental disorders including, but not limited to, PTSD (Basu et al., 2020; D'Andrea

77 et al., 2012), somatic syndromes (Afari et al., 2014), and poor physical health (O'Donovan et al.,

78 2011) in later adolescence and adulthood, we sought to develop a scale that would not only

79 identify adolescents who meet DSM-5 PTSD diagnostic criteria (American Psychiatric

80 Association, 2013), but also those with any functionally-impairing post-trauma symptoms,

81 including subsyndromal PTSD (Alessi et al., 2013). Individuals with subsyndromal PTSD

82 experience substantial functional difficulties that require mental health treatment (Pietrzak et

83 al., 2012) and often progress to full PTSD (Fink et al., 2018). The need to identify youth with

84 post-trauma symptoms who might not meet full diagnostic criteria for PTSD may be particularly

85 pertinent when trying to identify high-risk youth who may be expected to present with less

86 severe symptoms than individuals detected through routine clinical care (Sonis, 2013).

87 Additionally, we sought to identify patients with trauma-related symptoms due to a non-DSM-5

88 Criterion A trauma such as relationship difficulties, non-violent deaths of loved ones, bullying,

89 and separation from parents. PTSD symptoms following non-Criterion A trauma are often

90 similar to, or sometimes worse than, those reported after Criterion A traumas (Lansing et al.,

91 2017). Early identification and treatment of all of these adolescent patients may prevent more

92 severe problems and is therefore of interest to pediatrics providers.

93 The three aims of this study were to (1) develop the Adolescent Primary Care Traumatic

94 Stress Screen (APCTSS), a screener that is feasible and acceptable for pediatrics, (2) pilot the

95 APCTSS in an adolescent medicine clinic, and (3) assess its psychometric properties, including

96 the internal structure of the scale, its concurrent and discriminant validity, and its

97 sensitivity/specificity and clinical cut point for identifying PTSD, subsyndromal PTSD, or

98 clinically impairing symptoms associated with a non-Criterion A distressing event.

\section{Study Site}


medRxiv preprint doi: https://doi.org/10.1101/2022.02.11.22270757; this version posted February 15, 2022. The copyright holder for this preprint (which was not certified by peer review) is the author/funder, who has granted medRxiv a license to display the preprint in perpetuity. It is made available under a CC-BY-NC-ND 4.0 International license .

This study was conducted in [edited out for blind review], which treats patients aged 12-

10222 years old. [edited out for blind review] is the largest safety-net hospital in [edited out for

103 blind review], with $57 \%$ percent of patients from underserved populations and $72 \%$ insured by

104 government payors ([edited out for blind review]). This study was approved and overseen by the

105 [edited out for blind review] IRB (\#).

\section{Procedures}

The 31-item UCLA PTSD Reaction Index for DSM-5 (UCLA-RI-5; Steinberg et al., 2013),

108 a well-validated PTSD scale for children and adolescents, was adapted and combined with the 5-

109 item adult Primary Care PTSD Screen for DSM-5 (PC-PTSD-5; Prins et al., 2016). Six attending-

110 level healthcare providers in the BMC Departments of Psychiatry (two psychologists and one

111 psychiatrist) and Pediatrics (one adolescent medicine physician and two social workers) with

112 expertise in diagnosing and treating PTSD in adolescents independently identified UCLA-RI-5

113 items corresponding to each of the items on the PC-PTSD-5.

114 The results of the mapping exercise were presented to five clinicians in the BMC

115 Department of Psychiatry who are experts in diagnosing and treating PTSD in adolescents

116 (three psychiatrists and two psychologists), of which three also participated in the item

117 mapping. The five experts reached consensus on which of the identified UCLA-RI- 5 items they

118 thought best represented the symptom profile of PTSD in adolescents and best discriminated

119 adolescents with PTSD from those with other mental health disorders (See Table 1 for consensus

120 results). The first and fourth authors refined and adapted the item language and instructions to

121 develop an introductory prompt.

\section{Results: Aim 1 - Development of the APCTSS}

At least four of the six raters believed that 11 items from the UCLA-RI- 5 corresponded to

124 at least one of the five items on the PC-PTSD-5 (See Table 2). There was consensus that both of

125 the UCLA-RI-5 items that corresponded to PC-PTSD-5 item \# 1 (nightmares) were more likely to

126 be present in adolescents with PTSD than adolescents with other mental disorders, and these 
medRxiv preprint doi: https://doi.org/10.1101/2022.02.11.22270757; this version posted February 15, 2022. The copyright holder for this preprint (which was not certified by peer review) is the author/funder, who has granted medRxiv a license to display the preprint in perpetuity. It is made available under a CC-BY-NC-ND 4.0 International license .

Adolescent Primary Care Traumatic Stress Screen

127 items were retained. For PC-PTSD-5 item \# 2 (avoidance), the UCLA-RI-5 item describing

128 imaginal rather than physical avoidance was selected, since many adolescents are unable to

129 physically avoid reminders of trauma. To represent PC-PTSD-5 item \# 3 (hyperarousal) they

130 selected an item that did not include being on the lookout for danger, as this may be a common

131 response for non-symptomatic adolescents exposed to potentially dangerous environments. The

132 experts agreed that the two UCLA-RI-5 items that corresponded to PC-PTSD-5 item \#4

133 (numbing/detachment) did not adequately differentiate PTSD from other mental disorders in

134 adolescents, and neither were retained. Two of the UCLA-RI-5 items that corresponded to PC-

135 PTSD-5 item \#5 (guilt/blame) were deemed to discriminate between PTSD and other mental

136 disorders and were combined into one. The UCLA-RI-5 item "I have thoughts like I am bad" was

137 not retained due to strong overlap with symptoms of depression and anxiety. The initial prompt

138 for the APCTSS was adapted from the UCLA-RI-5 self-report trauma history screener (See

139 Figure 1 for the complete APCTSS measure).

Method: Aim 2 - Assessment of the Psychometric Properties of the APCTSS

141 Recruitment

142 When a researcher was available for assessment, all adolescent medicine patients seen in

143 the clinic were informed about the study and invited to participate. Patients over 18 provided

144 verbal informed consent, while patients under 18 and a legal guardian provided verbal assent

145 and consent, respectively. Recruitment took place in the waiting room and in examination

146 rooms while patients were waiting to be seen by clinic staff. Informed consent and completion of

147 study measures took place either in a private therapy office or in an examination room.

148 Participants

149 Participants were 178 patients aged $13-22(M=18.4, S D=2.3)$ who visited the clinic

150 between December 2018 and February 2020. The majority (83.6\%) of patients approached

151 agreed to participate, and $4.7 \%$ were excluded due to being unable to complete the study

152 requirements in English. Almost two-thirds of the sample were female (64.4\%), 23.6\% were 
medRxiv preprint doi: https://doi.org/10.1101/2022.02.11.22270757; this version posted February 15, 2022. The copyright holder for this preprint (which was not certified by peer review) is the author/funder, who has granted medRxiv a license to display the preprint in perpetuity. It is made available under a CC-BY-NC-ND 4.0 International license .

Adolescent Primary Care Traumatic Stress Screen

153 male, and $12.0 \%$ were transgender or non-binary. In terms of race/ethnicity, $62.1 \%$ of

154 participants identified as Black or African-American, 20.7\% identified as Hispanic or Latino,

$1559.4 \%$ identified as White or Caucasian, and 7.4\% identified as another race/ethnicity or as multi-

156 racial. Sample demographics were reflective of the overall clinic population.

157 Sample Size and Power

158 The sample size goal was 200 participants based on a power calculation assuming a

159 sample prevalence rate of PTSD of $30 \%$, a sensitivity of 0.85 and specificity of 0.90 with $95 \%$ CI

160 half widths of 0.09 for sensitivity and 0.07 for specificity. We had collected data on 178 of 200

161 participants by the end of February 2020, when data collection was stopped due to Covid-19.

162 Due to uncertain timeline of resumed in-person data collection, we concluded data collection at

163178 participants.

164 Measures

165 The APCTSS was developed in earlier phases of the study and described above. Self-

166 reported depression was assessed using the Patient Health Questionnaire for Adolescents (PHQ-

167 A; ,Johnson et al., 2002), a nine-item survey designed for use in primary care with adolescents

168 aged 13-18. The Traumatic Events Screening Inventory for Children (TESI-C; Ford et al., 2002)

169 assessed potentially traumatic events. Participant responses were classified as Criterion A

170 traumatic events in accordance with DSM-5 guidelines (American Psychiatric Association, 2013;

171 Pai et al., 2017). PTSD symptoms were assessed using the Child PTSD Symptom Scale for DSM-

1725 Interview (CPSS-5-I; Foa et al., 2018). which has been validated with youth between the ages

173 of 8 and 18 . Cronbach's alpha of the symptom scale was .95 in this sample. The CPSS-5-I

174 interview begins with a prompt asking participants to "tell me about the most upsetting or scary

175 experience you've ever had" and then provides examples (Foa et al., 2018). Interviewers

176 recorded the participant's most upsetting experiences and when they occurred, and also

177 separately recorded whether the experiences included actual or threatened death, serious injury,

178 or sexual violation. After recording the most upsetting event, the interviewers used the CPSS- 5 -I 
medRxiv preprint doi: https://doi.org/10.1101/2022.02.11.22270757; this version posted February 15, 2022. The copyright holder for this preprint (which was not certified by peer review) is the author/funder, who has granted medRxiv a license to display the preprint in perpetuity. It is made available under a CC-BY-NC-ND 4.0 International license .

Adolescent Primary Care Traumatic Stress Screen

179 to assess the frequency of 20 PTSD symptoms that participants experienced in the past month

180 related to the most upsetting event. Symptoms were rated on a 5-point Likert scale ( $0=$ not at all;

$1814=6$ or more times a week/almost always). Finally, the CPSS-5-I assesses the frequency of

182 functional impairment due to PTSD symptoms across seven domains using the same Likert

183 scale.

Participants were classified as having PTSD if they reported a Criterion A trauma and at

185 least all of the following: one intrusion item, one avoidance item, two changes in cognition and

186 mood items, two increased arousal and reactivity items, and three impairment items (American

187 Psychiatric Association, 2013; Foa et al., 2018). Participants were classified as having sub-

188 syndromal PTSD if they endorsed a Criterion A trauma and at least two symptom categories and

189 one functional impairment item (American Psychiatric Association, 2013). Participants were

190 classified as having post-distressing event symptoms if they endorsed at least two symptom

191 categories and at least one functional impairment item, but did not report a qualifying Criterion

192 A trauma.

193 Study Procedures

194 After informed consent, participants independently completed the APCTSS and PHQ-A

195 with pencil and paper, which is the typical form of PTSD screener administration (Brewin,

196 2005; Spoont et al., 2013) and which is also the standard screening approach in the clinic. Upon

197 completion of the two screeners, two researchers members, who were a PhD candidate in

198 Applied Human Development and a clinical psychology master's student, verbally administered

199 the CPSS-5-I as an interview (Foa et al., 2018) and participants completed a demographic

200 questionnaire on their own using pencil and paper. The researchers were blind to the participant

201 responses on the APCTSS and the PHQ-A.

202 During data collection, researchers suspected that some participants who reported non-

203 Criterion A events as their most upsetting experience in response to the open-ended prompt

204 may have also experienced a Criterion A trauma. Therefore, after the first 9 months of data 
medRxiv preprint doi: https://doi.org/10.1101/2022.02.11.22270757; this version posted February 15, 2022. The copyright holder for this preprint (which was not certified by peer review) is the author/funder, who has granted medRxiv a license to display the preprint in perpetuity. It is made available under a CC-BY-NC-ND 4.0 International license .

Adolescent Primary Care Traumatic Stress Screen

205 collection, we started administering the TESI-C (Ford et al., 2002), a trauma events checklist, to

206 evaluate whether participants who completed an inventory of traumatic events reported the

207 same rates of Criterion A trauma as those who were just asked to share the most scary or

208 upsetting event they had experienced when prompted during the CPSS-5-I. The initial open-

209 ended prompt on the CPSS-5-I about "the most upsetting or scary experiences you've ever had"

210 was asked first, then researchers verbally administered the TESI-C, and then the researchers

211 administered the remaining PTSD symptoms and functional impairment items of the CPSS-5-I.

212 Approximately one-third of participants $(N=61)$ had the TESI-C verbally administered after the

213 CPSS-5-I open-ended prompt, and prior to the CPSS-5-I symptom and functional impairment

214 assessment. All participants received a \$5 cash card for their participation.

\section{Statistical analysis}

216 Analysis included examining (1) the internal structure of the APCTSS using Cronbach's

217 alpha, (2) concurrent and discriminant validity using Pearson's correlation coefficients with the

218 CPSS-5-I and the PHQ-A, and (3) sensitivity and specificity to differentiate participants with

219 and without PTSD and optimal diagnostic cutoff scores for the APCTSS through the use of

220 receiver operating characteristic (ROC) analysis and calculation of the Youden index. In

221 addition, we compared the ability of the APCTSS to identify adolescents at risk of subsyndromal

222 PTSD symptoms or undetected trauma exposure who would otherwise not be identified by the

223 PHQ-A. Post-hoc ROC analyses were run on the subset of participants who completed the TESI-

224 C to assess area under the curve (AUC), sensitivity, and specificity when accounting for trauma

225 disclosed on the TESI-C when assessing Criterion A for PTSD diagnosis.

Results: Aim 2 - Assessment of the Psychometric Properties of the APCTSS

\section{Descriptive Statistics}

Over half of the sample (57.3\%) endorsed at least one item on the APCTSS, and $39.3 \%$

229 endorsed two or more items (See Table 2 for item-level descriptives). More than half (56.7\%) of

230 participants reported experiencing a criterion A trauma on either the TESI-C or CPSS-5-I. 
medRxiv preprint doi: https://doi.org/10.1101/2022.02.11.22270757; this version posted February 15, 2022. The copyright holder for this preprint (which was not certified by peer review) is the author/funder, who has granted medRxiv a license to display the preprint in perpetuity. It is made available under a CC-BY-NC-ND 4.0 International license .

Adolescent Primary Care Traumatic Stress Screen

231 Participants who completed the TESI-C were more likely to report Criterion A trauma

232 experiences $(71.2 \%)$ than those who did not $(49.6 \%), \chi 2(1)=7.50, p<.01$. The average score on

233 the CPSS-5-I symptom scale was $20.28(S D=17.60)$ regardless of whether they had a qualifying

234 criterion A trauma, indicating that the average BMC adolescent medicine primary care patient

235 endorsed moderate levels of PTSD symptoms. Almost one-third (30.1\%) met criteria for PTSD,

$2367.4 \%$ met criteria for subsyndromal PTSD, and an additional 19.0\% met criteria for post-event

237 impairing symptoms. The average score on the PHQ-A was $5.80(S D=5.39)$, indicating non-

238 clinical levels of depression symptoms. Results of Fisher's exact tests indicated that there were

239 no differences in PTSD rates (Fisher's exact $=0.78$ ), at least subsyndromal PTSD (Fisher's exact

$240=1.67$ ), or at least impairing symptoms (Fisher's exact $=1.23$ ) by race/ethnicity, although we

241 were underpowered to detect differences for White or multiracial or other race youth.

\section{Internal Consistency}

243 The Cronbach's alpha coefficient for the APCTSS was .77, which is considered adequate.

244 Coefficient alpha did not improve significantly with the removal of any of the 5 items.

245 Sensitivity, Specificity, and Positive and Negative Predictive Value

246 ROC analysis and the Youden index score indicated that a score of 2 or higher on the

247 APCTSS was associated with optimal values for sensitivity (.79; 95\% CI=.66 to .89) and

248 specificity (.68; 95\% CI = .59 to .76) for PTSD diagnosis (see Table 3 ). A cut-off score of 2

249 yielded a positive predictive value (PPV) of .55 (95\% CI $=.47$ to .62 ) and a negative predictive

250 value (NPV) of $.87(95 \% \mathrm{CI}=.80$ to .92$)$. The area under the curve (AUC) was .79. A cut-off

251 score of 2 was also the optimal cut-off for detecting sub-syndromal PTSD, with a sensitivity of

252.78 (95\% CI=.67 to .88), specificity of .73 (95\% CI=.64 to .82), AUC of .81 , and a Youden index of

253 .51. A cut-off score of 2 resulted in 16 false positives (9.0\%; i.e., youth identified as being at high

254 risk on the screener, but did not have PTSD, sub-syndromal PTSD, or post-event impairing

255 symptoms), but missed 32 youth (18.0\%) who had impairing symptoms. Comparatively, a score 
medRxiv preprint doi: https://doi.org/10.1101/2022.02.11.22270757; this version posted February 15, 2022. The copyright holder for this preprint

(which was not certified by peer review) is the author/funder, who has granted medRxiv a license to display the preprint in perpetuity.

It is made available under a CC-BY-NC-ND 4.0 International license .

Adolescent Primary Care Traumatic Stress Screen

256 of 1 resulted in 41 (23.0\%) false positives but only missed $12(6.7 \%)$ youth who did have these

257 symptoms, of which four had PTSD.

258 Results of the post-hoc ROC analyses were run on the subset of participants who

259 completed the TESI-C to assess AUC, sensitivity, and specificity when accounting for Criterion A

260 trauma exposure that was not reported in response to the open-ended prompt on the CPSS-5-I.

261 A cut-off score of 2 was also the optimal cut-point for the subset of participants who completed

262 the TESI-C, but sensitivity (.86; $95 \% \mathrm{CI}=.65$ to .90$)$, specificity (.77; $95 \% \mathrm{CI}=.60$ to .90$)$, PPV

$263(.70 ; 95 \% \mathrm{CI}=.56$ to .82$)$, NPV $(.90 ; 95 \% \mathrm{CI}=.76$ to .96$)$ and AUC (.86) were stronger for PTSD

264 diagnosis compared to the full sample. Similar results were observed for subsyndromal PTSD

265 and post-event impairing symptoms (See Table 3 for complete results).

266 Concurrent Validity

267 The APCTSS was strongly correlated with the total CPSS-5-I symptom score $(r=.71, p<$ $268.001)$ and the total score for impairment items $(r=.62, p<.001)$.

269 Discriminant Validity

270

The APCTSS was moderately correlated with the PHQ-A $(r=.55, p<.001)$, and the

271 association was significantly lower than the association between the APCTSS and the CPSS-5-I

$272(z=3.87, p<.001$; Steiger, 1980$)$. Over half of patients $(56.0 \%)$ who screened positive on the

273 APCTSS (score $\geq 2$ ) would not have been flagged using the PHQ-A, including $60.8 \%$ of patients

274 who had probable PTSD, subsyndromal PTSD, or post-event impairing symptoms.

275

Discussion

276 The need for a feasible and valid primary care PTSD screener for pediatrics is high. In

277 this sample, more than $55 \%$ of adolescents presenting for primary care reported experiencing a

278 criterion A trauma, 30\% met DSM-5 diagnostic criteria for PTSD, and a further 26\% either had

279 sub-syndromal PTSD or post-event impairing symptoms. All together, $56 \%$ had functionally

280 impairing symptoms associated with a traumatic or difficult event. Although the PTSD

281 prevalence rate found in this study was high, results also suggest that our study may have 
medRxiv preprint doi: https://doi.org/10.1101/2022.02.11.22270757; this version posted February 15, 2022. The copyright holder for this preprint (which was not certified by peer review) is the author/funder, who has granted medRxiv a license to display the preprint in perpetuity. It is made available under a CC-BY-NC-ND 4.0 International license .

Adolescent Primary Care Traumatic Stress Screen

282 actually underestimated the prevalence of PTSD in our sample. Because more participants who

283 were administered the TESI-C endorsed criterion A traumas than participants who were only

284 asked to report trauma in response to an open ended prompt, it is possible that the false positive

285 rate on the screener was artificially inflated because some of those false positives would have

286 qualified for PTSD or sub-syndromal PTSD had we administered the TESI-C, since more of

287 them likely would have endorsed criterion A experiences. The finding of somewhat higher

288 trauma reports using a trauma checklist has been observed in other studies that specifically

289 sought to answer this question (Monson et al., 2016). Therefore, it is likely that more than $30 \%$

290 of the adolescent patients seen in routine pediatric primary care at BMC have PTSD, which is

291 often not detected. The high rates of PTSD and post-trauma symptoms identified by this study

292 emphasize the need to have a psychometrically sound and feasible traumatic stress screener for

293 use in pediatric primary care, particularly clinics serving a low-income and BIPOC youth.

294 The PTSD prevalence in this sample is much higher than rates found from

295 epidemiological studies (Merikangas et al., 2010), but is similar to other populations of youth

296 who receive primary care services in safety net hospitals or federally qualified health centers

297 (Selwyn et al., 2019) which serve a higher proportion of patients who are racial/ethnic

298 minorities, non-English speaking, uninsured, underinsured, undocumented, or low-income

299 (Gaskin \& Hadley, 1999; Lasser et al., 2021; Nath et al., 2016). Our study sample was more than

$30060 \%$ Black or African-American and more than 21\% Hispanic or Latino, which mirrors the

301 overall BMC pediatric primary care clinic population. Although we did not collect data on

302 income or socioeconomic status, more than $70 \%$ of BMC patients are insured by government

303 payors (Boston Medical Center, 2016), a blunt proxy for low-income status. Low-income and

304 BIPOC (black, indigenous, and people of color) youth are disproportionately affected by traumatic

305 and adverse events (Giano et al., 2020; Mersky et al., 2021), which are at least partially downstream

306 outcomes of structural inequities. Indeed, structural inequities arise from exploitative power

307 dynamics (Laster Pirtle, 2020; Prins et al., 2021), as do most types of trauma. Prejudice, 
medRxiv preprint doi: https://doi.org/10.1101/2022.02.11.22270757; this version posted February 15, 2022. The copyright holder for this preprint

(which was not certified by peer review) is the author/funder, who has granted medRxiv a license to display the preprint in perpetuity.

It is made available under a CC-BY-NC-ND 4.0 International license .

Adolescent Primary Care Traumatic Stress Screen

308 discrimination, and systemic or structural inequities such as policies, practices, and behaviors that

309 perpetuate disparities in wealth, housing, education, employment, healthcare, and opportunities can

310 be traumatic themselves (Mikhail et al., 2018). Moreover, they create conditions that increase the

311 likelihood that low-income and BIPOC youth will be exposed to other traumas, such as violence and

312 death (Knopov et al., 2019; Wilkins et al., 2019). One consequence of the disproportionate exposure

313 to trauma and ACEs that low-income and BIPOC youth cope with is a higher rate of subsequent

314 PTSD and associated mental health symptoms and disorders (Lopez et al., 2017; Price et al., 2019;

315 Pulsifer et al., 2019).

316 This study developed and pilot tested the Adolescent Primary Care Traumatic Stress

317 Screen (APCTSS), the first PTSD and traumatic stress screener for adolescents developed

318 specifically for pediatric primary care. The development process leveraged expert and

319 stakeholder knowledge by asking pediatricians, psychiatrists, psychologists, and social workers

320 who all provide care to trauma-affected adolescent patients in BMC to identify common post-

321 trauma symptoms expressed by their patients, to refine the language in the measure to be

322 developmentally appropriate, to ensure that items accurately reflect symptoms rather than

323 environmental or social stressors which may disproportionately impact some youth or

324 communities (i.e., not including 'being on the lookout for danger"'), and to create a feasible and

325 useable measure that would have a very high likelihood of being adopted into routine practice in

326 an urban safety net pediatric primary care clinic. Validity and reliability testing indicated that

327 the APCTSS is internally consistent, has good concurrent and discriminant validity, and is

328 effective at identifying adolescents at high risk for post-trauma symptoms and PTSD.

329 Our results suggest that a cut-off score of 2 on the APCTSS is appropriate for correctly

330 identifying adolescents who are at high risk of having PTSD or related symptoms and require

331 further assessment. The AUC of .79 was comparable to the AUC rate of other PTSD screeners

332 used in primary care, which range from .75 to .93 (Spoont et al., 2013). and an AUC of 0.7 and

333 higher is generally considered strong in the field of applied psychology (Rice \& Harris, 2005). 
medRxiv preprint doi: https://doi.org/10.1101/2022.02.11.22270757; this version posted February 15, 2022. The copyright holder for this preprint (which was not certified by peer review) is the author/funder, who has granted medRxiv a license to display the preprint in perpetuity. It is made available under a CC-BY-NC-ND 4.0 International license .

Adolescent Primary Care Traumatic Stress Screen

334 Moreover, a cut-off score of 2 yielded a PPV of .55 (95\% CI = .47 to .62) and a NPV of .87 (95\%

$335 \mathrm{CI}=.80$ to .92 ), in line with the performance of the PC-PTSD in in routine care primary care

336 samples (0.41 and 0.97, respectively; Ouimette et al., 2008) and in rigorous validity studies

337 (0.51 and 0.99. respectively; Prins et al., 2016).

338 While the results of the ROC curve analysis were strong for the full sample, they were

339 even better in the sub-sample of participants who completed the TESI-C, with an AUC of .86, a

340 sensitivity of $.86(95 \% \mathrm{CI}=.65$ to .90$)$ and specificity of .77 (95\% CI=.60 to .90). The results

341 suggest that the lower scores in the full sample may be better explained by misclassification of

342 some participants with PTSD as not having PTSD rather than inaccurate detection of the

343 APCTSS. It is likely that the true classification accuracy of the APCTSS is closer to an AUC of .86

344 than .79. Regardless, the APCTSS was quite successful in accurately detecting high risk

345 participants in this sample, demonstrating internal reliability, convergent validity, sensitivity,

346 and specificity comparable to the Child Trauma Screen (CTS), a 10-item measure that uses a

347 four-point Likert scale, and has also been validated (but not developed) in pediatric primary

348 care (Lang et al., 2021b). However, the brevity, simplicity, and lack of a traumatic events scale of

349 the APCTSS, along with its similar psychometric properties to longer screeners evaluated in

350 pediatric primary care, may increase its likelihood of being adopted as the measure of choice in

351 routine pediatric primary care, just as the PC-PTSD- 5 has been adopted in routine adult primary

352 care (Bovin et al., 2021).

353 Notably, almost 70\% of patients who screened positive on the APCTSS would not have

354 been detected by the PHQ-A (Johnson et al., 2002). This included over half who had PTSD,

355 subsyndromal PTSD, or post-event impairing symptoms. Reliance solely on generalized distress

356 and depression scales to screen for common mental disorders may miss more than $50 \%$ of

357 adolescents with trauma-related distress and impairment, similar to findings with adult samples

358 (Ouimette et al., 2008). Including a brief screener for PTSD symptoms may identify youth

359 coping with PTSD who would otherwise not receive care. 
medRxiv preprint doi: https://doi.org/10.1101/2022.02.11.22270757; this version posted February 15, 2022. The copyright holder for this preprint (which was not certified by peer review) is the author/funder, who has granted medRxiv a license to display the preprint in perpetuity. It is made available under a CC-BY-NC-ND 4.0 International license .

Adolescent Primary Care Traumatic Stress Screen

Researchers have noted that the evidence base for universal screening of PTSD in

361 primary care is limited, and therefore universal screening is not yet warranted. However, they

362 suggest that targeted screening of patients who spontaneously report PTSD symptoms (Sonis,

363 2013) or trauma exposure, have other mental health or substance abuse problems, or who are

364 non-responsive to treatment for insomnia or pain (Greene et al., 2016), should be screened for

365 trauma-related symptoms. This approach may be more cost-effective and would be expected to

366 result in higher specificity and sensitivity (Sonis, 2013). The APCTSS could help fill the gap in

367 pediatric primary care by providing a tool to quickly screen these high-risk patients.

368 Results must be interpreted within the limitations of the methods, including the reliance on

369 youth self-report. However, the goal was to identify adolescents using self-report methods in

370 assessing the APCTSS, and adolescents tend to be accurate reporters of internalizing distress

371 (Weems et al., 2005), and so we concluded that self-report assessments would be appropriate. A

372 second limitation was the lack of a clinician administered structured clinical interview, although

373 we did utilize the interview version of the CPSS-5. Studies have found correlations exceeding .90

374 between self-report PTSD symptom scales and clinician rated structured interviews (Blanchard

375 et al., 1996), and so we primarily utilized self-report measures for ease of administration. Future

376 studies should validate the APCTSS using a clinician-rated structured clinical interview.

377 This study is also limited by the lack of inclusion a trauma event checklist for most of the

378 participants. The inclusion of the TESI-C for the last $34 \%$ of participants allowed us to identify

379 more participants that qualified for PTSD or subsyndromal PTSD, and it is likely that we

380 misclassified earlier participants as having post-event impairing symptoms when they met

381 criteria for PTSD or subsyndromal PTSD. A further limitation is that our sample size did not

382 allow us to look at psychometric properties by race/ethnicity or gender, and we did not include a

383 measure of socioeconomic status. Future studies should utilize a larger sample size to assess

384 differential validity or reliability across different demographic variables. 
medRxiv preprint doi: https://doi.org/10.1101/2022.02.11.22270757; this version posted February 15, 2022. The copyright holder for this preprint (which was not certified by peer review) is the author/funder, who has granted medRxiv a license to display the preprint in perpetuity. It is made available under a CC-BY-NC-ND 4.0 International license .

Adolescent Primary Care Traumatic Stress Screen

In addition, there was overlap of expert participants during the two phases of the

386 development of the measure, such that three experts participated in step one, which was

387 independently identifying UCLA-RI-5 items that corresponded to PC-PTSD-5 items, and also

388 participated in step two, which was the consensus discussion of the results from step one to

389 select specific items for inclusion on the APCTSS. It may be that the overlap in participants

390 decreased the variance in expert opinion or biased the results in step two. However, we believe

391 that use of both an independent rating and a consensus rating also strengthened item selection.

392 Finally, the APCTSS was developed and validated in the BMC Department of Pediatrics'

393 adolescent medicine clinic and results may not be generalizable to other clinics or populations.

394 However, the purpose was to develop a measure that was contextually and culturally

395 appropriate for a busy urban safety net pediatrics clinic and its patients. We believe that the

396 resulting measure, which capitalizes on expert and stakeholder feedback, UCLA-RI-5 and PC-

397 PTSD-5 items, and reliability and validity assessed in routine care in a diverse population makes

398 it potentially generalizable to many clinics. The study also had several other strengths which

399 have typically been limitations of the other studies of primary care PTSD screeners (Spoont et

400 al., 2013), including universally approaching and enrolling primary care patients, non-selective

401 recruitment for CPSS-5-I administration, and conducting the CPSS-5-I without knowledge of

402 the results of the APCTSS.

\section{Conclusion}

Many youth with trauma-related mental health symptoms and functional impairment have

405 not been identified in pediatric primary care. This missed opportunity for early identification,

406 prevention, and intervention, may have contributed to a host of poor outcomes for these youth.

407 The development of an effective and feasible PTSD screening tool for youth primary care may

408 improve the health and well-being for some of our most vulnerable adolescents. 
medRxiv preprint doi: https://doi.org/10.1101/2022.02.11.22270757; this version posted February 15, 2022. The copyright holder for this preprint (which was not certified by peer review) is the author/funder, who has granted medRxiv a license to display the preprint in perpetuity. It is made available under a CC-BY-NC-ND 4.0 International license .

Adolescent Primary Care Traumatic Stress Screen

Afari, N., Ahumada, S. M., Wright, L. J., Mostoufi, S., Golnari, G., Reis, V., \& Cuneo, J. G.

\section{References} (2014). Psychological Trauma and Functional Somatic Syndromes: A Systematic Review and Meta-Analysis. Psychosomatic Medicine, 76(1). https://journals.lww.com/psychosomaticmedicine/Fulltext/2014/01000/Psychological Trauma and Functional Somatic.2.aspx

Alessi, E. J., Meyer, I. H., \& Martin, J. I. (2013). PTSD and sexual orientation: An examination of criterion A1 and non-criterion A1 events. Psychological Trauma: Theory, Research, Practice, and Policy, 5(2), 149-157. https://doi.org/10.1037/a0026642

Alisic, E., Zalta, A. K., van Wesel, F., Larsen, S. E., Hafstad, G. S., Hassanpour, K., \& Smid, G. E. (2014). Rates of post-traumatic stress disorder in trauma-exposed children and adolescents: meta-analysis. Br J Psychiatry, 204, 335-340. https://doi.org/10.1192/bjp.bp.113.131227

American Psychiatric Association. (2013). Diagnostic and statistical manual of mental disorders, Fifth Edition (Fifth ed.). American Psychiatric Publishing.

Banh, M. K., Saxe, G., Mangione, T., \& Horton, N. J. (2008, Nov-Dec). Physician-reported practice of managing childhood posttraumatic stress in pediatric primary care. Gen Hosp Psychiatry, 3o(6), 536-545. https://doi.org/10.1016/j.genhosppsych.2008.07.008

Basu, A., Farkas, D. K., Jiang, T., Koenen, K. C., Lash, T. L., Sørensen, H. T., \& Gradus, J. L. (2020). Incident psychiatric comorbidity following stress disorder diagnoses in Danish school-aged children: prospective population-based study. The British Journal of Psychiatry, 217(1), 377-382. https://doi.org/10.1192/bjp.2019.247

Blanchard, E. B., Jones-Alexander, J., Buckley, T. C., \& Forneris, C. A. (1996, 1996/08/01/). Psychometric properties of the PTSD checklist (PCL). Behaviour Research and Therapy, 34(8), 669-673. https://doi.org/https://doi.org/10.1016/0005-7967(96)00033-2 
medRxiv preprint doi: https://doi.org/10.1101/2022.02.11.22270757; this version posted February 15, 2022. The copyright holder for this preprint (which was not certified by peer review) is the author/funder, who has granted medRxiv a license to display the preprint in perpetuity. It is made available under a CC-BY-NC-ND 4.0 International license .

Adolescent Primary Care Traumatic Stress Screen

Boston Medical Center. (2016). Boston Medical Center Community Health Needs Assessment Final Report. https://www.bmc.org/sites/default/files/About_Us/Commitment to Our Community /field Attachments/BMC-Community-HealthNeedsAssessment-HNA.pdf

Bovin, M. J., Kimerling, R., Weathers, F. W., Prins, A., Marx, B. P., Post, E. P., \& Schnurr, P. P. (2021, Feb 1). Diagnostic Accuracy and Acceptability of the Primary Care Posttraumatic Stress Disorder Screen for the Diagnostic and Statistical Manual of Mental Disorders (Fifth Edition) Among US Veterans. JAMA Netw Open, 4(2), e2036733. https://doi.org/10.1001/jamanetworkopen.2020.36733

Brewin, C. R. (2005). Systematic review of screening instruments for adults at risk of PTSD. Journal of Traumatic Stress, 18(1), 53-62. https://doi.org/https://doi.org/10.1002/jts.20007

California Department of Health Care Services. (2021, 12/30/2020). Trauma Screenings and Trauma-Informed Care Provider Trainings. https://www.dhcs.ca.gov/provgovpart/Pages/TraumaCare.aspx

D'Andrea, W., Ford, J., Stolbach, B., Spinazzola, J., \& van der Kolk, B. A. (2012, Apr). Understanding interpersonal trauma in children: why we need a developmentally appropriate trauma diagnosis. Am J Orthopsychiatry, 82(2), 187-200. https://doi.org/10.1111/j.1939-0025.2012.01154.x

Fink, D. S., Gradus, J. L., Keyes, K. M., Calabrese, J. R., Liberzon, I., Tamburrino, M. B., Cohen, G. H., Sampson, L., \& Galea, S. (2018, Nov). Subthreshold PTSD and PTSD in a prospective-longitudinal cohort of military personnel: Potential targets for preventive interventions. Depress Anxiety, 35(11), 1048-1055. https://doi.org/10.1002/da.22819

Foa, E. B., Asnaani, A., Zang, Y., Capaldi, S., \& Yeh, R. (2018, Jan-Feb). Psychometrics of the Child PTSD Symptom Scale for DSM-5 for Trauma-Exposed Children and Adolescents. $J$ 
medRxiv preprint doi: https://doi.org/10.1101/2022.02.11.22270757; this version posted February 15, 2022. The copyright holder for this preprint (which was not certified by peer review) is the author/funder, who has granted medRxiv a license to display the preprint in perpetuity. It is made available under a CC-BY-NC-ND 4.0 International license .

Adolescent Primary Care Traumatic Stress Screen

Clin Child Adolesc Psychol, 47(1), 38-46. https://doi.org/10.1080/15374416.2017.1350962

Ford, J., Racusin, R., Rogers, K., Ellis, C., Schiffman, J., Ribbe, D., \& Edwards, J. (2002). Traumatic events screening inventory for children (TESI-C) Version 8.4. National Center for PTSD and Dartmouth Child Psychiatry Research Group.

Gaskin, D. J. P., \& Hadley, J. P. (1999). Population characteristics of markets of safety-net and non-safety-net hospitals. Journal of Urban Health, 76(3), 351-370. https://doi.org/http://dx.doi.org/10.1007/BF02345673

Gerson, R., \& Rappaport, N. (2013, Feb). Traumatic stress and posttraumatic stress disorder in youth: recent research findings on clinical impact, assessment, and treatment. $J$ Adolesc Health, 52(2), 137-143. https://doi.org/10.1016/j.jadohealth.2012.06.018

Giano, Z., Wheeler, D. L., \& Hubach, R. D. (2020, 2020/09/10). The frequencies and disparities of adverse childhood experiences in the U.S. BMC Public Health, 2O(1), 1327. https://doi.org/10.1186/s12889-020-09411-z

Goldstein, E., Athale, N., Sciolla, A. F., \& Catz, S. L. (2017). Patient Preferences for Discussing Childhood Trauma in Primary Care. Perm J, 21, 16-055. https://doi.org/10.7812/tpp/16055

Gore, K. L., Engel, C. C., Freed, M. C., Liu, X., \& Armstrong, D. W., 3rd (2008). Test of a singleitem posttraumatic stress disorder screener in a military primary care setting. Gen Hosp Psychiatry, 30(5), 391-397. https://doi.org/https://doi.org/10.1016/j.genhosppsych.2008.05.002

Greene, T., Neria, Y., \& Gross, R. (2016, 2016/06/01). Prevalence, Detection and Correlates of PTSD in the Primary Care Setting: A Systematic Review. Journal of Clinical Psychology in Medical Settings, 23(2), 160-180. https://doi.org/10.1007/s10880-016-9449-8

Johnson, J. G., Harris, E. S., Spitzer, R. L., \& Williams, J. B. (2002, Mar). The patient health questionnaire for adolescents: validation of an instrument for the assessment of mental 
medRxiv preprint doi: https://doi.org/10.1101/2022.02.11.22270757; this version posted February 15, 2022. The copyright holder for this preprint (which was not certified by peer review) is the author/funder, who has granted medRxiv a license to display the preprint in perpetuity. It is made available under a CC-BY-NC-ND 4.0 International license .

Adolescent Primary Care Traumatic Stress Screen disorders among adolescent primary care patients. $J$ Adolesc Health, 3o(3), 196-204. https://doi.org/10.1016/s1054-139x(01)00333-0

Kassam-Adams, N., \& Marsac, M. L. (2016). Brief Practical Screeners in English and Spanish for Acute Posttraumatic Stress Symptoms in Children. Journal of Traumatic Stress, 29(6), 483-490. https://doi.org/10.1002/jts.22141

Kenardy, J. A., Spence, S. H., \& Macleod, A. C. (2006). Screening for Posttraumatic Stress Disorder in Children After Accidental Injury. Pediatrics, 118(3), 1002-1009. https://doi.org/10.1542/peds.2006-0406

Knopov, A., Rothman, E. F., Cronin, S. W., Franklin, L., Cansever, A., Potter, F., Mesic, A., Sharma, A., Xuan, Z., Siegel, M., \& Hemenway, D. (2019, Feb). The Role of Racial Residential Segregation in Black-White Disparities in Firearm Homicide at the State Level in the United States, 1991-2015. J Natl Med Assoc, 111(1), 62-75. https://doi.org/10.1016/j.jnma.2018.06.002

Kroenke, K., Spitzer, R. L., \& Williams, J. B. (2003, Nov). The Patient Health Questionnaire-2: validity of a two-item depression screener. Med Care, 41(11), 1284-1292. https://doi.org/10.1097/01.Mlr.0000093487.78664.3c

Lang, A. J., Wilkins, K., Roy-Byrne, P. P., Golinelli, D., Chavira, D., Sherbourne, C., Rose, R. D., Bystritsky, A., Sullivan, G., Craske, M. G., \& Stein, M. B. (2012). Abbreviated PTSD Checklist (PCL) as a guide to clinical response. Gen Hosp Psychiatry, 34(4), 332-338. https://doi.org/https://doi.org/10.1016/j.genhosppsych.2012.02.003

Lang, J. M., \& Connell, C. M. (2017, May). Development and validation of a brief trauma screening measure for children: The Child Trauma Screen. Psychol Trauma, 9(3), 390398. https://doi.org/10.1037/tra0000235

Lang, J. M., \& Connell, C. M. (2018). The Child Trauma Screen: A Follow-Up Validation. Journal of Traumatic Stress, 31(4), 540-548. https://doi.org/https://doi.org/10.1002/jts.22310 
medRxiv preprint doi: https://doi.org/10.1101/2022.02.11.22270757; this version posted February 15, 2022. The copyright holder for this preprint (which was not certified by peer review) is the author/funder, who has granted medRxiv a license to display the preprint in perpetuity. It is made available under a CC-BY-NC-ND 4.0 International license .

Adolescent Primary Care Traumatic Stress Screen

513 Lang, J. M., Connell, C. M., \& Macary, S. (2021a). Validating the Child Trauma Screen Among a Cross-Sectional Sample of Youth and Caregivers in Pediatric Primary Care. Clinical Pediatrics, 6o(4/5), 252-258. https://doi.org/https://doi.org/10.1177/00099228211005302

Lang, J. M., Connell, C. M., \& Macary, S. (2021b, May). Validating the Child Trauma Screen Among a Cross-Sectional Sample of Youth and Caregivers in Pediatric Primary Care. Clin Pediatr (Phila), 6o(4-5), 252-258. https://doi.org/10.1177/00099228211005302

Lansing, A. E., Plante, W. Y., \& Beck, A. N. (2017, 2017/05/01/). Assessing stress-related treatment needs among girls at risk for poor functional outcomes: The impact of cumulative adversity, criterion traumas, and non-criterion events. Journal of anxiety disorders, 48, 36-44. https://doi.org/https://doi.org/10.1016/j.janxdis.2016.09.007

Lasser, K. E., Liu, Z., Lin, M.-Y., Paasche-Orlow, M. K., \& Hanchate, A. (2021). Changes in Hospitalizations at US Safety-Net Hospitals Following Medicaid Expansion. JAMA Network Open, 4(6), e2114343-e2114343. https://doi.org/10.1001/jamanetworkopen.2021.14343

Laster Pirtle, W. N. (2020, Aug). Racial Capitalism: A Fundamental Cause of Novel Coronavirus (COVID-19) Pandemic Inequities in the United States. Health Educ Behav, 47(4), 504508. https://doi.org/10.1177/1090198120922942

Lopez, C. M., Andrews, A. R., Chisolm, A. M., de Arellano, M. A., Saunders, B., \& Kilpatrick, D.

535 Löwe, B., Kroenke, K., \& Gräfe, K. (2005, 2005/02/01/). Detecting and monitoring depression 536 with a two-item questionnaire (PHQ-2). Journal of Psychosomatic Research, 58(2), 163171. https://doi.org/https://doi.org/10.1016/j.jpsychores.2004.09.006 
medRxiv preprint doi: https://doi.org/10.1101/2022.02.11.22270757; this version posted February 15, 2022. The copyright holder for this preprint (which was not certified by peer review) is the author/funder, who has granted medRxiv a license to display the preprint in perpetuity. It is made available under a CC-BY-NC-ND 4.0 International license .

Adolescent Primary Care Traumatic Stress Screen

Merikangas, K. R., He, J.-p., Burstein, M., Swanson, S. A., Avenevoli, S., Cui, L., Benjet, C., Georgiades, K., \& Swendsen, J. (2010, 07/31). Lifetime Prevalence of Mental Disorders in US Adolescents: Results from the National Comorbidity Study-Adolescent Supplement (NCS-A). Journal of the American Academy of Child and Adolescent Psychiatry, 49(10), 980-989. https://doi.org/10.1016/j.jaac.2010.05.017

Mersky, J. P., Choi, C., Plummer Lee, C., \& Janczewski, C. E. (2021, 2021/07/01/). Disparities in adverse childhood experiences by race/ethnicity, gender, and economic status: Intersectional analysis of a nationally representative sample. Child Abuse \& Neglect, 117, 105066. https://doi.org/https://doi.org/10.1016/j.chiabu.2021.105066

Mikhail, J. N., Nemeth, L. S., Mueller, M., Pope, C., \& NeSmith, E. G. (2018, Sep/Oct). The Social Determinants of Trauma: A Trauma Disparities Scoping Review and Framework. J Trauma Nurs, 25(5), 266-281. https://doi.org/10.1097/JTN.0000000000000388

Monson, E., Lonergan, M., Caron, J., \& Brunet, A. (2016). Assessing trauma and posttraumatic stress disorder: Single, open-ended question versus list-based inventory. Psychological Assessment, 28(8), 1001-1008. https://doi.org/10.1037/pasoo00223

Nath, J. B., Costigan, S., \& Hsia, R. Y. (2016). Changes in Demographics of Patients Seen at Federally Qualified Health Centers, 2005-2014. JAMA Intern Med, 176(5), 712-714. https://doi.org/10.1001/jamainternmed.2016.0705

O'Donovan, A., Sun, B., Cole, S., Rempel, H., Lenoci, M., Pulliam, L., \& Neylan, T. (2011). Transcriptional control of monocyte gene expression in post-traumatic stress disorder. Dis Markers, 3o(2-3), 123-132. https://doi.org/10.3233/dma-2011-0768

Ouimette, P., Wade, M., Prins, A., \& Schohn, M. (2008, 2008/01/01/). Identifying PTSD in primary care: Comparison of the Primary Care-PTSD Screen (PC-PTSD) and the General Health Questionnaire-12 (GHQ). Journal of anxiety disorders, 22(2), 337-343. https://doi.org/https://doi.org/10.1016/j.janxdis.2007.02.010 
medRxiv preprint doi: https://doi.org/10.1101/2022.02.11.22270757; this version posted February 15, 2022. The copyright holder for this preprint (which was not certified by peer review) is the author/funder, who has granted medRxiv a license to display the preprint in perpetuity. It is made available under a CC-BY-NC-ND 4.0 International license .

Adolescent Primary Care Traumatic Stress Screen

563

564

565

566

567

568

569

570

571

572

573

574

575

576

577

578

579

580

581

582

583

584

585

586

587

Pai, A., Suris, A. M., \& North, C. S. (2017). Posttraumatic Stress Disorder in the DSM-5:

Controversy, Change, and Conceptual Considerations. Behavioral sciences (Basel, Switzerland), 7(1), 7. https://doi.org/10.3390/bs7010007

Pietrzak, R. H., Schechter, C. B., Bromet, E. J., Katz, C. L., Reissman, D. B., Ozbay, F., Sharma, V., Crane, M., Harrison, D., Herbert, R., Levin, S. M., Luft, B. J., Moline, J. M., Stellman, J. M., Udasin, I. G., Landrigan, P. J., \& Southwick, S. M. (2012, 2012/07/01/). The burden of full and subsyndromal posttraumatic stress disorder among police involved in the World Trade Center rescue and recovery effort. Journal of Psychiatric Research, 46(7), 835-842. https://doi.org/https://doi.org/10.1016/j.jpsychires.2012.03.011

Price, J., Genuario, K., Romeo, D., Pruden, K., Elwell, S., Matwiejewicz, D., Friedlander, E., \& Jaszczyszyn, D. (2019, Feb). Implementation of a standardized screening program for risk of posttraumatic stress disorder among youth hospitalized with injury. Psychol Serv, 16(1), 48-57. https://doi.org/10.1037/ser0000271

Prins, A., Bovin, M. J., Smolenski, D. J., Marx, B. P., Kimerling, R., Jenkins-Guarnieri, M. A., Kaloupek, D. G., Schnurr, P. P., Kaiser, A. P., Leyva, Y. E., \& Tiet, Q. Q. (2016, October 01). The Primary Care PTSD Screen for DSM-5 (PC-PTSD-5): Development and Evaluation Within a Veteran Primary Care Sample. Journal of General Internal Medicine, 31(10), 1206-1211. https://doi.org/10.1007/s11606-016-3703-5

Prins, A., Ouimette, P., Kimerling, R., Cameron, R. P., Hugelshofer, D. S., Shaw-Hegwer, J., Thrailkill, A., Gusman, F. D., \& Sheikh, J. I. (2003). The primary care PTSD screen (PCPTSD): Development and operating characteristics. Primary Care Psychiatry, 9(1), 9-14. https://doi.org/10.1185/135525703125002360

Prins, S. J., McKetta, S., Platt, J., Muntaner, C., Keyes, K. M., \& Bates, L. M. (2021, Mar 1). The Serpent of Their Agonies: Exploitation as Structural Determinant of Mental Illness. Epidemiology, 32(2), 303-309. https://doi.org/10.1097/EDE.0000000000001304 
medRxiv preprint doi: https://doi.org/10.1101/2022.02.11.22270757; this version posted February 15, 2022. The copyright holder for this preprint (which was not certified by peer review) is the author/funder, who has granted medRxiv a license to display the preprint in perpetuity. It is made available under a CC-BY-NC-ND 4.0 International license .

Adolescent Primary Care Traumatic Stress Screen

Pulsifer, B. H., Evans, C. L., Capel, L., Lyons-Hunter, M., \& Grieco, J. A. (2019). Cross-sectional assessment of mental health and service disparities in a high-risk community. Translational Issues in Psychological Science, 5(4), 365-373. https://doi.org/10.1037/tpso000211

Read, J., McGregor, K., Coggan, C., \& Thomas, D. R. (2006, 2006/04/04). Mental Health Services and Sexual Abuse: The Need for Staff Training. Journal of Trauma \& Dissociation, 7(1), 33-50. https://doi.org/10.1300/J229v07n01 04

Rice, M. E., \& Harris, G. T. (2005, Oct). Comparing effect sizes in follow-up studies: ROC Area, Cohen's d, and r. Law Hum Behav, 29(5), 615-620. https://doi.org/10.1007/s10979$\underline{005-6832-7}$

Selwyn, C. N., Schneider, M., Anderson, C., \& Langhinrichsen-Rohling, J. (2019). Recognizing the hurt: Prevalence and correlates of elevated PTSD symptoms among adolescents receiving mental/behavioral health services in primary care. Psychological Services, 16(1), 58-66. https://doi.org/10.1037/sero000322 (Trauma-Informed Care for Children and Families)

Sonis, J. (2013, 2013/05/28). PTSD in Primary Care-An Update on Evidence-based Management. Current Psychiatry Reports, 15(7), 373. https://doi.org/10.1007/s11920013-0373-4

Spoont, M., Arbisi, P., Fu, S., Greer, N., Kehle-Forbes, S., Meis, L., Rutks, I., \& Wilt, T. J. (2013). VA Evidence-based Synthesis Program Reports. In Screening for Post-Traumatic Stress Disorder (PTSD) in Primary Care: A Systematic Review. Department of Veterans Affairs (US).

Spoont, M. R., Williams, J. W., Jr., Kehle-Forbes, S., Nieuwsma, J. A., Mann-Wrobel, M. C., \& Gross, R. (2015, Aug 4). Does This Patient Have Posttraumatic Stress Disorder?: Rational Clinical Examination Systematic Review. JAMA, 314(5), 501-510. https://doi.org/10.1001/jama.2015.7877 
medRxiv preprint doi: https://doi.org/10.1101/2022.02.11.22270757; this version posted February 15, 2022. The copyright holder for this preprint (which was not certified by peer review) is the author/funder, who has granted medRxiv a license to display the preprint in perpetuity. It is made available under a CC-BY-NC-ND 4.0 International license .

Adolescent Primary Care Traumatic Stress Screen

614 Steiger, J. H. (1980). Tests for comparing elements of a correlation matrix. Psychological Bulletin, 87(2), 245-251. https://doi.org/10.1037/0033-2909.87.2.245

616 Steinberg, A. M., Brymer, M. J., Kim, S., Briggs, E. C., Ippen, C. G., Ostrowski, S. A., Gully, K. J., \& Pynoos, R. S. (2013, Feb). Psychometric properties of the UCLA PTSD reaction index: part I. J Trauma Stress, 26(1), 1-9. https://doi.org/10.1002/jts.21780

Turner, H. A., Finkelhor, D., \& Ormrod, R. (2010, Mar). Poly-victimization in a national sample of children and youth. Am J Prev Med, 38(3), 323-330. https://doi.org/10.1016/j.amepre.2009.11.012

Weems, C. F., Zakem, A. H., Costa, N. M., Cannon, M. F., \& Watts, S. E. (2005, Dec).

Wilkins, N. J., Zhang, X., Mack, K. A., Clapperton, A. J., Macpherson, A., Sleet, D., KresnowSedacca, M. J., Ballesteros, M. F., Newton, D., Murdoch, J., Mackay, J. M., BereckiGisolf, J., Marr, A., Armstead, T., \& McClure, R. (2019, Aug). Societal determinants of violent death: The extent to which social, economic, and structural characteristics explain differences in violence across Australia, Canada, and the United States. SSM Popul Health, 8, 100431. https://doi.org/10.1016/j.ssmph.2019.100431

Wurr, C. J., \& Partridge, I. M. (1996, 1996/09/01/). The prevalence of a history of childhood sexual abuse in an acute adult inpatient population. Child Abuse \& Neglect, 2O(9), 867872. https://doi.org/https://doi.org/10.1016/0145-2134(96)00074-9 
Table 1. Items from the UCLA-RI-5 that corresponded to the PC-PTSD-5, as rated by expert clinicians

PC-PTSD-5 Items UCLA-RI-5 Items Expert Consensus

1. Have had a. I have had bad dreams about what This item discriminates between PTSD and other mental

nightmares about it

or thought about it

when you did not

want to?

2. Tried hard not to

think about it or went out of your way to avoid

situations that reminded you of it?

3. Were constantly on guard, watchful, or easily startled?

4. Felt numb or detached from others, activities, or your surroundings?

5. Felt guilty or unable happened or other bad dreams.

b. I have upsetting thoughts, pictures or sounds of what happened come into my mind when I don't want them to.

a. I try to stay away from people, places, or things that remind about what happened.

b. I try not to think about or have feelings about what happened.

a. I am on the lookout for danger or things that I am afraid of.

b. I feel jumpy or startle easily, like when I hear a loud noise or when something surprises me.

a. I don't feel like doing things with my family or friends or other things that I liked to do.

b. I feel alone even when I am around other people.

a. I have thoughts like I am bad. disorders and should be retained

This item discriminates between PTSD and other mental disorders and should be retained

Physical avoidance may not always be possible, particularly for youth who are still living in the environment or context in which the trauma occurred

This item discriminates between PTSD and other mental disorders and should be retained

This may be a reasonable response for adolescents living in dangerous or unstable environments

This item discriminates between PTSD and other mental disorders and should be retained

This symptom does not discriminate well between PTSD and other mental disorders

This symptom does not discriminate well between PTSD and other mental disorders

This symptom does not discriminate well between PTSD 
Adolescent Primary Care Traumatic Stress Screen

to stop blaming

yourself or others

for the event(s) or

any other problems

the event(s) may

have caused? and other mental disorders

b. I am mad with someone for making the bad thing happen, not doing more to stop it, or to help after.

c. I feel that part of what happened was my fault.
Discriminates between PTSD and other mental disorders but can be combined with \#5c below

Discriminates between PTSD and other mental disorders but can be combined with \#5b above 
Table 2. Item-level descriptive statistics for the APCTSS

\begin{tabular}{lcc}
\hline \multicolumn{1}{c}{ Item } & Percentage of & $\begin{array}{c}\text { participants endorsing } \\
\text { item }\end{array}$ \\
& & $41.60 \%$ \\
\hline $\begin{array}{l}\text { Bad dreams about scary experiences or other bad dreams } \\
\text { Upsetting thoughts, pictures or sounds of scary experiences come into your } \\
\text { mind when you didn't want them to }\end{array}$ & 61 & $34.30 \%$ \\
$\begin{array}{l}\text { Tried not to think about or have feelings about scary experiences } \\
\text { Mad at yourself or someone else for making the scary experiences happen, }\end{array}$ & 70 & $39.30 \%$ \\
$\begin{array}{l}\text { not doing more to stop it, or to help after } \\
\text { Felt jumpy or easily startled, like when you hear a loud noise or when }\end{array}$ & $79.50 \%$ \\
something surprises you? & 79 & $44.40 \%$ \\
\hline
\end{tabular}


Adolescent Primary Care Traumatic Stress Screen

Table 3. Number and Percent of participants with PTSD diagnoses and symptoms compared to APCTSS scores

\begin{tabular}{|c|c|c|c|c|c|c|}
\hline APCTSS Score & $\begin{array}{c}\mathbf{o} \\
\mathbf{n}(\%) \\
\end{array}$ & $\begin{array}{c}1 \\
\text { n (\%) }\end{array}$ & $\begin{array}{c}2 \\
\text { n (\%) }\end{array}$ & $\begin{array}{c}\mathbf{3} \\
\mathbf{n}(\%) \\
\end{array}$ & $\begin{array}{c}4 \\
\text { n (\%) } \\
\end{array}$ & $\begin{array}{c}5 \\
\mathbf{n}(\%) \\
\end{array}$ \\
\hline Participants with score & $53(29.8 \%)$ & $45(25.3 \%)$ & $24(13.5 \%)$ & $20(11.2 \%)$ & $16(9.0 \%)$ & $20(11.2 \%)$ \\
\hline Participants with score AND PTSD & $4(7.6 \%)$ & $7(15.6 \%)$ & $9(37.5 \%)$ & $10(50.0 \%)$ & $7(43.8 \%)$ & $16(80.0 \%)$ \\
\hline $\begin{array}{l}\text { Participants with score AND probable } \\
\text { subsyndromal PTSD }\end{array}$ & o $(0 \%)$ & $3(6.67 \%)$ & $3(12.5 \%)$ & $2(10 \%)$ & $2(12.5 \%)$ & $2(10 \%)$ \\
\hline $\begin{array}{l}\text { Participants with score AND post-event } \\
\text { impairing symptoms (non-Criterion A event) }\end{array}$ & $8(15.1 \%)$ & $10(22.2 \%)$ & $4(16.7 \%)$ & $3(15.0 \%)$ & $5(31.3 \%)$ & $1(5 \%)$ \\
\hline $\begin{array}{l}\text { Participants with the score and either PTSD, } \\
\text { subsyndromal PTSD, or post-event impairing } \\
\text { symptoms (non-Criterion A event) }\end{array}$ & $12(22.6 \%)$ & $20(44.4 \%)$ & $16(66.7 \%)$ & $15(75.0 \%)$ & $14(87.5 \%)$ & $19(95.0 \%)$ \\
\hline $\begin{array}{l}\text { Participants without post-event or post-trauma } \\
\text { impairing symptoms }\end{array}$ & $41(77.3 \%)$ & $25(55.6 \%)$ & $8(33.3 \%)$ & $5(25.0 \%)$ & $2(12.5 \%)$ & $1(5.0 \%)$ \\
\hline
\end{tabular}




\section{Figure 1. The Adolescent Primary Care Traumatic Stress Screen (APCTSS)}

\section{Adolescent Primary Care Traumatic Stress Screen (APCTSS)}

Sometimes people have scary, violent, or upsetting experiences where someone could have been badly hurt or killed.

In the past month, have you:

\begin{tabular}{|l|l|l|l|}
\hline & \multicolumn{1}{|l|}{} & Yes & No \\
\hline 1) & Had bad dreams about scary experiences or other bad dreams? & & \\
\hline 2) & $\begin{array}{l}\text { Had upsetting thoughts, pictures or sounds of scary experiences come into your } \\
\text { mind when you didn't want them to? }\end{array}$ & & \\
\hline 3$)$ & Tried not to think about or have feelings about scary experiences? & & \\
\hline 4$)$ & $\begin{array}{l}\text { Been mad at yourself or someone else for making the scary experiences happen, }, \\
\text { not doing more to stop it, or to help after? }\end{array}$ & & \\
\hline 5) & $\begin{array}{l}\text { Felt jumpy or easily startled, like when you hear a loud noise or when } \\
\text { something surprises you? }\end{array}$ & & \\
\hline
\end{tabular}

